\title{
Workshop Pembuatan Media Pembelajaran Interaktif dalam Memenuhi Tuntutan Pembelajaran Abad 21
}

\author{
Lalu Muhammad Fauzi*1, Muhammad Gazali ${ }^{2}$, Husnul Mukti ${ }^{3}$, Baiq Fitri Rahmawati ${ }^{4}$ \\ lmfauzi@hamzanwadi.ac.id ${ }^{* 1}$ \\ ${ }^{1}$ Program Studi Pendidikan Matematika, FMIPA, Universitas Hamzanwadi \\ ${ }^{2}$ Program Studi Statistika, FMIPA, Universitas Hamzanwadi \\ ${ }^{3}$ Program Studi Pendidikan Guru Sekolah Dasar, FIP, Universitas Hamzanwadi \\ ${ }^{4}$ Program Studi Pendidikan Sejarah, FISE, Universitas Hamzanwadi
}

Received: 22 October 2021 Accepted: 07 December 2021 Online Publisher: 30 December 2021

DOI: 10.29408/ab.v2i2.4115

\begin{abstract}
Abstrak: Guru memiliki peran yang sangat penting dalam membina dan mengarahkan siswa untuk dapat berkompetisi di segala bidang. Era globalisasi menuntut guru untuk dapat meningkatkan kompetensi pedagoginya terutama pada kompetensi profesional. Guru tidak hanya dituntut untuk piawai dalam memahami materi pelajaran akan tetapi guru juga harus mampu menggunakan dan memanfaatkan teknologi sebagai media dan sumber belajar. Untuk meningkatkan hal tersebut dianggap penting untuk memberikan workshop atau pelatihan dalam pembuatan dan pemanfaatan media pembelajaran interaktif demi kelancaran pembelajaran di masa pandemik Covid-19 seperti saat ini. Workshop dilaksanakan selama tiga hari dengan rincian pemberian materi pada hari pertama, praktik pembuatan media pada hari kedua dan evaluasi produk yang dihasilkan peserta pada hari ketiga, yang dilaksanakan mulai pada hari Sabtu, 5 Agustus sampai dengan hari Senin, 7 Agustus 2021 bertempat di SDN 3 Sembalun Bumbung. Hasil workshop memberikan gambaran bahwa peserta telah mampu membuat media pembelajaran interaktif dengan menggunakan aplikasi Auto Play Media Studio 8.0 kalaupun masih perlu perbaikan untuk penyempurnaan, akan tetapi hasil atau produk yang dibuat sudah dapat digunakan atau diimplementasikan dalam pembelajaran.
\end{abstract}

Kata kunci: Media Pembelajaran Interaktif; Pembelajaran Abad 21; Workshop

\begin{abstract}
Teachers have a crucial role in fostering and directing students to compete in all fields. The era of globalization requires teachers to improve their pedagogical competence, especially in professional competence. Teachers are needed to be proficient in understanding the subject matter, but teachers must also be able to use and utilize technology as a medium and source of learning. It is vital to provide workshops or training to create and use interactive learning media for smooth learning during the current COVID-19 pandemic. The workshop was held for three days with details on the provision of material on the first day, the practice of making media on the second day, and evaluation of the products produced by the participants on the third day, which was held from Saturday, August 5, to Monday, August 7, 2021, at SDN 3 Sembalun Bumbung. The workshop results illustrate that participants have been able to create interactive learning media using the AutoPlay Media Studio 8.0 application.
\end{abstract}

Keywords: $21^{\text {st }}$ Century Learning; Interactive Learning Media; Workshop 
Fauzi, L. M., Gazali, M., Mukti, H., Rahmawati, B. F. (2021) Workshop pembuatan media pembelajaran interaktif dalam memenuhi tuntutan pembelajaran Abad 21. ABSYARA: Jurnal Pengabdian Pada Masyarakat, 2(2), 185-194. doi:10.29408/ab.v2i2.4115

\section{PENDAHULUAN}

Pendidikan merupakan salah satu aspek yang dapat membangun suatu negara ke arah yang lebih baik. Investasi yang disalurkan melalui pendidikan akan menciptakan sumber daya manusia yang kompeten. Pendidikan formal terjadi melalui pembelajaran di kelas dengan guru sebagai fasilitator. Guru memainkan peran utama dalam pembelajaran di sekolah, terutama karena guru adalah jembatan pengetahuan bagi semua siswa. Mengembangkan kemampuan dan membentuk watak serta peradaban bangsa yang bermartabat dalam rangka mencerdaskan kehidupan bangsa merupakan tujuan dari pendidikan Nasional. Hal ini termuat dalam UU No. 20 tahun 2003 tentang sistem pendidikan nasional, pemerintah menekankan pada profesionalisme guru, yaitu meningkatkan dan memahami standar kompetensi minimal yang harus dikuasai oleh seorang guru sebagai bentuk implementasi untuk memenuhi tujuan tersebut. Standar kompetensi yang dimaksud adalah kompetensi pedagogi, sosial, profesional, dan kepribadian. Pemenuhan dan penyiapan yang dilakukan oleh guru sebagai media pelayan jasa pendidikan merupakan bentuk tanggung jawab kepada masyarakat. Dengan demikian haruslah syarat kompetensi tersebut dimiliki dan dikuasai oleh seorang guru yang akan berdampak pada pelayanan kepada siswa menjadi optimal.

Saat ini dunia pendidikan telah mengalami perkembangan yang cukup dalam pengembangan ilmu pengetahuan dan teknologi. Pada era globalisasi seperti saat ini guru harus mengikuti perkembangan ilmu pengetahuan dan teknologi dalam proses pembelajaran terutama dalam menyiapkan bahan ajar dalam bentuk media pembelajaran interaktif (Arianti, dkk., 2020). Peningkatan kemampuan dalam menghadapi perkembangan teknologi yang sangat pesat pada sat ini, mau tidak mau harus diimbangi dengan kemampuan guru dalam memahami ilmu pengetahuan dan teknologi (Burns, 2011). Pemanfaatan teknologi sebagai bagian dari implementasi kebijakan Mendikbud yang menginginkan pemanfaatan teknologi menjadi bagian utama dalam proses pendidikan, tidak semudah yang dibayangkan. Hal ini dikarenakan persoalan yang dihadapi sangat kompleks, diantaranya adalah kurangnya pemahaman pengajar dan peserta didik dalam menggunakan teknologi sebagai media pembelajaran luring dan daring, mengakibatkan sering terjadinya ketidakmaksimalan proses pembelajaran, ditambah lagi dengan kemampuan ekonomi masyarakat yang rendah dalam memenuhi kebutuhan sekolah dalam pembelajaran daring (Fauzi, dkk., 2020).

Pada era globalisasi (dunia digital) seperti sekarang ini guru dituntut untuk berinovasi dan mengembangkan diri untuk memenuhi tantangan dalam dunia pendidikan. Globalisasi menuntut guru beradaptasi dan berkembang dengan cepat melalui karya-karya yang nyata. Sebagaimana tuntutan pembelajaran Abad-21 guru dituntut untuk memiliki keterampilan berupa: (1) Keterampilan Berpikir Kritis; (2) Kemampuan Menyelesaikan Masalah; (3) Komunikasi dan Kolaborasi; (4) Kreativitas dan Inovasi; (5) Literasi Media Informasi, Komunikasi, dan Teknologi (Lase, 2019). Perkembangan teknologi informasi komunikasi di Era Revolusi Industri 4.0 yang pesat memudahkan dalam keberlangsungan perkuliahan daring. Media sosial dapat dijadikan media pembelajaran daring karena dapat digunakan berkomunikasi antarmuka, berpartisipasi, dan berbagi (Samsuri, dkk., 2020)

Pembelajaran menggunakan media interaktif merupakan hal yang sangat penting, media pembelajaran merupakan sesuatu yang dapat menyampaikan pesan, merangsang berpikir, dan mendorong proses pembelajaran menjadi lebih mudah. Penggunaan media pembelajaran interaktif dapat memotivasi siswa untuk memahami materi pembelajaran (Vinod \& Pathak- 
Shelat, 2017). Salah satu komponen terpenting dalam proses pembelajaran adalah penggunaan media pembelajaran interaktif karena dengan adanya media pembelajaran tersebut dapat mempermudah pengajar dalam menyampaikan materi ajar yang akan disampaikan (Sumantri \& Rachmadtullah, 2016; Vebrianto \& Osman, 2011). Di dalam media interaktif dalam pembelajaran terdapat variasi dalam kegiatan belajar mengajar.

Beberapa penelitian menjelaskan hal ini disebabkan bagaimana media interaktif merupakan upaya penyampaian materi pembelajaran yang abstrak menjadi konkret (Vebrianto \& Osman, 2011; Zawacki-Richter, dkk., 2015). Media interaktif terbukti dapat meningkatkan motivasi belajar siswa, sehingga memudahkan siswa dalam memahami materi pembelajaran, selain itu media pembelajaran interaktif memiliki pengaruh yang signifikan dalam meningkatkan kompetensi peserta didik (McDougall \& Potter, 2015).

Pandemi Covid-19 belum berlalu, kebijakan belajar dari rumah masih berjalan sebagaimana kebijakan menteri pendidikan dan kebudayaan awal tahun 2020 yang lalu. Akibatnya guru harus berusaha untuk memenuhi tuntutan dengan mengembangkan diri di bidang teknologi dan komunikasi. Pembelajaran tatap muka saat ini sangat minim, menggunakan media baik dalam bentuk software dan hardware sangat digalakkan. Hal ini merupakan pekerjaan yang sangat berat dan kompleks bagi seorang guru. Dari hasil observasi yang dilakukan pada Kelompok Kerja Guru Gugus Mandiri-Rinjani (KKG Mandiri-Rinjani) Kecamatan Sembalun Kabupaten Lombok Timur - NTB diketahui bahwa masih banyak guru yang belum bisa mengembangkan dan menggunakan media dalam pembelajaran dengan optimal. Hal ini terlihat dari jumlah anggota KKG Gugus Rinjani Sembalun menurut ketuanya menyatakan bahwa hampir $80 \%$ belum mampu mengembangkan dan membuat media pembelajaran sendiri. Harus dipahami bersama bahwa peran media saat ini sangat besar karena dunia digital semakin berkembang dan pemahaman siswa terkait hal tersebut sangat signifikan.

Proses pembelajaran merupakan proses timbal balik antara guru dan siswa dengan melakukan komunikasi. Proses komunikasi sering kali tidak efektif yang diakibatkan oleh kemampuan guru dalam menyampaikan informasi serta kemampuan siswa dalam mengolah informasi, yang artinya bahwa tidak semua materi dapat dipahami dengan baik oleh siswa. Untuk mengantisipasi hal seperti ini kehadiran media dianggap sangat penting untuk mengubah suasana pembelajaran sehingga menjadi lebih bermakna. Media sebagai sebuah alat bantu dalam proses pembelajaran untuk mencapai tujuan yang diharapkan (Sadiman, 2002).

Dari kondisi yang dikemukakan di atas, tampaknya perlu dilakukan suatu kegiatan yang mampu meningkatkan pemahaman dan keterampilan para guru dalam mengembangkan kompetensi profesionalisme, khususnya dalam pengembangan dan desain media pembelajaran. Hal ini dilakukan melalui kegiatan pengabdian pada masyarakat sebagai salah satu implementasi dari kegiatan Tri Dharma Perguruan Tinggi. Bentuk kegiatan yang dilakukan adalah workshop pembuatan media pembelajaran interaktif yang digunakan dalam pembelajaran daring, untuk memenuhi tuntutan kebijakan menteri pendidikan dan kebudayaan dan tuntutan pembelajaran abad 21

\section{METODE PELAKSANAAN}

Kegiatan ini dirangkai dari beberapa tahapan. Kegiatan diawali dengan proses wawancara dalam kegiatan observasi yakni dengan tujuan untuk menemukan permasalahanpermasalahan yang dihadapi dan harapan yang dimiliki oleh guru. Setelah terjadi komunikasi 
Fauzi, L. M., Gazali, M., Mukti, H., Rahmawati, B. F. (2021) Workshop pembuatan media pembelajaran interaktif dalam memenuhi tuntutan pembelajaran Abad 21. ABSYARA: Jurnal Pengabdian Pada Masyarakat, 2(2), 185-194. doi:10.29408/ab.v2i2.4115

dengan ketua gugus, kami selaku tim selanjutnya mempersiapkan kebutuhan-kebutuhan untuk pelaksanaan workshop. Pada tahap ini, kegiatan akan dilaksanakan dengan model pelatihan pembuatan media pembelajaran interaktif. Pelatihan ini terdiri dari pemberian materi, praktik pembuatan media pembelajaran interaktif dan pendampingan peserta.

\section{Waktu dan tempat}

Pelaksanaan kegiatan workshop selama 3 hari bertempat di SDN 3 Sembalun Bumbung bekerja sama dengan Kelompok Kerja Guru (KKG) Rinjani Kecamatan Sembalun, dengan rincian hari pertama pemberian materi, hari kedua peserta belajar membuat media secara mandiri dan hari ketiga evaluasi hasil. Adapun jadwal kegiatan yang dimaksud sebagai berikut:

Tabel 1. Jadwal Kegiatan Pelatihan Pembuatan Media Pembelajaran Interaktif

\begin{tabular}{|c|c|c|c|}
\hline Jam & Kegiatan & Narasumber/Fasilitator & Moderator \\
\hline \multicolumn{4}{|c|}{ Sabtu, 5 Agustus 2021} \\
\hline $08.30-09.00$ & Registrasi peserta & - & Panitia \\
\hline $09.00-09.30$ & Pembukaan & Ketua panitia & Panitia \\
\hline $09.30-12.00$ & $\begin{array}{l}\text { Pemberian materi dan } \\
\text { praktik }\end{array}$ & Tim pengabdi & Panitia \\
\hline $12.00-13.30$ & Isoma & - & Panitia \\
\hline $13.30-16.00$ & Praktik lanjutan & Tim pengabdi & Panitia \\
\hline \multicolumn{4}{|c|}{ Minggu, 6 Agustus 2021} \\
\hline- & Praktik mandiri & - & - \\
\hline \multicolumn{4}{|c|}{ Senin, 7 Agustus 2021} \\
\hline $08.00-11.00$ & $\begin{array}{l}\text { Evaluasi produk peserta } \\
\text { melalui vicon }\end{array}$ & Tim pengabdi & - \\
\hline
\end{tabular}

\section{Prosedur pelaksanaan}

Prosedur atau tahap-tahap kegiatan workshop pembuatan media pembelajaran interaktif yang dilaksanakan di SDN 3 Sembalun Bumbung berikut ini:

Tabel 2. Tahap-tahap Kegiatan Pelatihan Pembuatan Media Pembelajaran Interaktif

\begin{tabular}{|c|c|c|c|c|}
\hline No. & Kegiatan & Penjelasan & Sasaran & Output \\
\hline 1 & Sosialisasi & $\begin{array}{l}\text { Penyampaian informasi } \\
\text { tentang program pengabdian } \\
\text { masyarakat dengan } \\
\text { melakukan } \\
\text { penjaringan masalah dan } \\
\text { membuat analisis solusi yang } \\
\text { dapat dilaksanakan }\end{array}$ & Tim pengabdi & $\begin{array}{l}\text { Dokumen } \\
\text { kerja sama }\end{array}$ \\
\hline 2 & Perencanaan & $\begin{array}{l}\text { Tim melakukan } \\
\text { pengumpulan data tentang } \\
\text { guru, membuat proposal, } \\
\text { serta mempersiapkan bahan- }\end{array}$ & $\begin{array}{l}\text { Guru, dan Tim } \\
\text { Pengabdian }\end{array}$ & $\begin{array}{l}\text { Dokumen } \\
\text { Proposal } \\
\text { pelaksanaan }\end{array}$ \\
\hline
\end{tabular}




\begin{tabular}{|c|c|c|c|c|}
\hline & & $\begin{array}{l}\text { bahan berupa materi dan } \\
\text { bahan praktik }\end{array}$ & & \\
\hline 3 & Pelaksanaan & $\begin{array}{l}\text { Dilaksanakan pelatihan } \\
\text { pembuatan media } \\
\text { pembelajaran interaktif } \\
\text { dengan cara didampingi dan } \\
\text { dibimbing oleh narasumber } \\
\text { dan tim pengabdian }\end{array}$ & Guru & $\begin{array}{l}\text { Produk hasil } \\
\text { workshop }\end{array}$ \\
\hline 4 & Evaluasi & $\begin{array}{lcr}\text { Narasumber } & \text { dan } & \text { tim } \\
\text { pengabdian } & \text { menilai } & \text { hasil } \\
\text { kerja peserta } & & \\
\end{array}$ & Guru & $\begin{array}{l}\text { Perbaikan } \\
\text { produk }\end{array}$ \\
\hline 5 & Pelaporan & $\begin{array}{l}\text { Tim pemberdayaan membuat } \\
\text { laporan kegiatan dari awal } \\
\text { sampai akhir kegiatan dalam } \\
\text { bentuk artikel }\end{array}$ & Tim pengabdian & $\begin{array}{l}\text { Dokumen } \\
\text { laporan hasil }\end{array}$ \\
\hline
\end{tabular}

\section{HASIL DAN PEMBAHASAN HASIL}

Workshop dilaksanakan dalam waktu 3 hari yakni mulai hari Sabtu, 5 Agustus sampai dengan hari Senin 7 Agustus 2021. Kegiatan ini terbagi dalam tiga tahapan yaitu:

\section{Hari pertama}

Pelaksanaan workshop hari pertama mulai jam 08.30 Wita, dengan kegiatan registrasi peserta yang dilakukan oleh panitia. Peserta yang terdaftar dan mengikuti workshop sebanyak 55 orang dari 8 sekolah anggota Kelompok Kerja Guru (KKG) Gugus Rinjani Kecamatan Sembalun. Pada pukul 08.30-09.00 Wita pembukaan workshop oleh panitia, dengan memberikan beberapa penguatan dalam sambutan yang diberikan oleh ketua panitia sekaligus ketua KKG Gugur Rinjani Kecamatan Sembalun. Pada sambutannya memaparkan pentingnya peningkatan kompetensi dalam menghadapi pembelajaran abad 21 yang salah satunya adalah peningkatan di bidang penguasaan teknologi pembelajaran yakni pengembangan media pembelajaran interaktif yang diterapkan pada masa pandemik Covid-19 saat ini. Selanjutnya pada pukul 09.00-12.00 Wita pelaksanaan workshop yang dimulai dengan pemaparan materi terkait program atau aplikasi yang digunakan yakni penjelasan atau tutorial penggunaan aplikasi Auto Play Media Studio 8.0 yang digunakan dalam membuat media pembelajaran interaktif. Tim pengabdian telah menyiapkan bahan yang akan dijadikan praktik yang terdiri dari software Auto Play Media Studio 8.0, buku panduan praktik, materi pelajaran, dan gambargambar yang akan dijadikan sebagai latar belakang dari media yang akan dibuat. Pada sesi ini narasumber yang terdiri dari tiga orang membagi tugas yakni satu orang sebagai pemateri praktik dan dua orang sebagai pendamping praktik yang berada di tengah peserta. Narasumber memandu cara penginstalan program yang akan digunakan. Pelaksanaan workshop berjalan sebagaimana yang diharapkan namun terdapat beberapa kendala yang dihadapi yakni terdapat beberapa laptop yang tidak mendukung program, terdapat beberapa laptop peserta yang tidak dapat dioperasikan. Antusias peserta setelah melihat beberapa contoh pembelajaran interaktif yang telah disiapkan oleh tim pengabdian sangat baik hal ini terlihat dari keinginan untuk 
mengembangkan diri bagi peserta sangat tinggi. Dengan melihat motivasi dari peserta kami selaku tim pengabdian menjadi bergairah untuk memberikan pendampingan sehingga peserta memahami dan dapat membuat media pembelajaran interaktif yang akan digunakan dalam pembelajaran nantinya. Pada pukul 12.00 - 13.30 Wita sesi istirahat Shalat dan makan siang. Kemudian dilanjutkan lagi pada pukul 13.30 - 16.00 Wita yakni praktik lanjutan pembuatan media pembelajaran interaktif. Hasil dari pelaksanaan hari pertama memberikan gambaran bahwa peserta telah memahami dan mampu membuat media pembelajaran walaupun masih berupa draf yang sederhana. Kegiatan hari pertama dapat dilihat pada gambar di bawah ini:

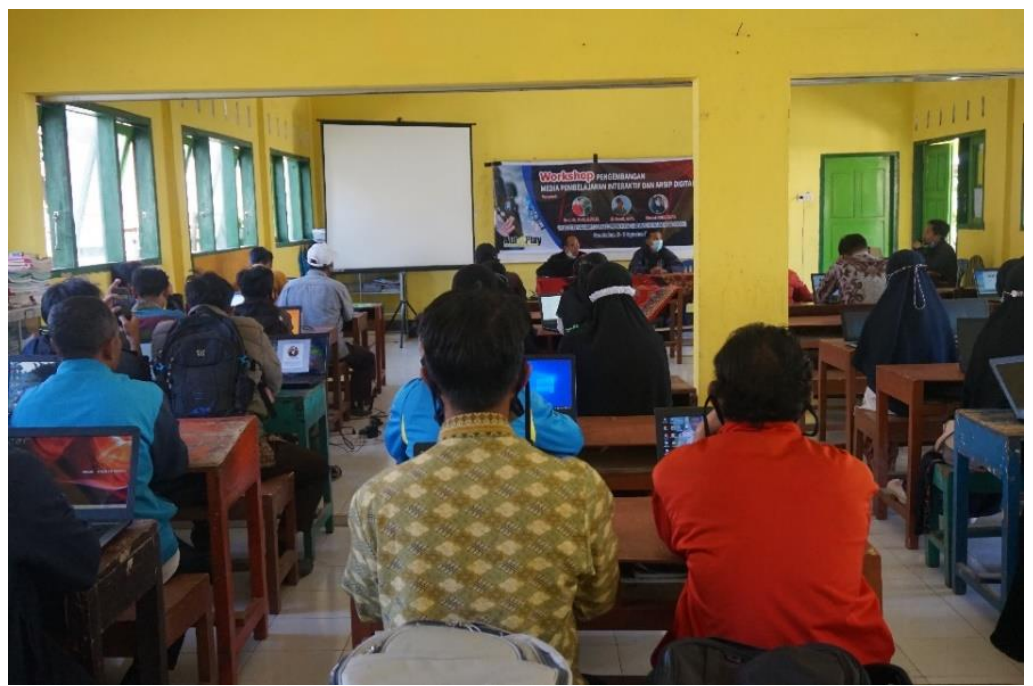

Gambar 1. Pembukaan workshop oleh ketua panitia

Ketua Kelompok Kerja Gugu (KKG) Gugus Rinjani Kecamatan Sembalun sekaligus sebagai ketua panitia membuka acara workshop dengan memberikan pemaparan bahwa KKG Gugus Rinjani akan menindak lanjuti kegiatan ini dengan meminta pendampingan bekerja sama dengan pihak Universitas Hamzanwadi untuk tetap menjalin hubungan dalam meningkatkan kompetensi bagi guru-guru yang ada di KKG Gugus Rinjani dalam bidangbidang yang lain.

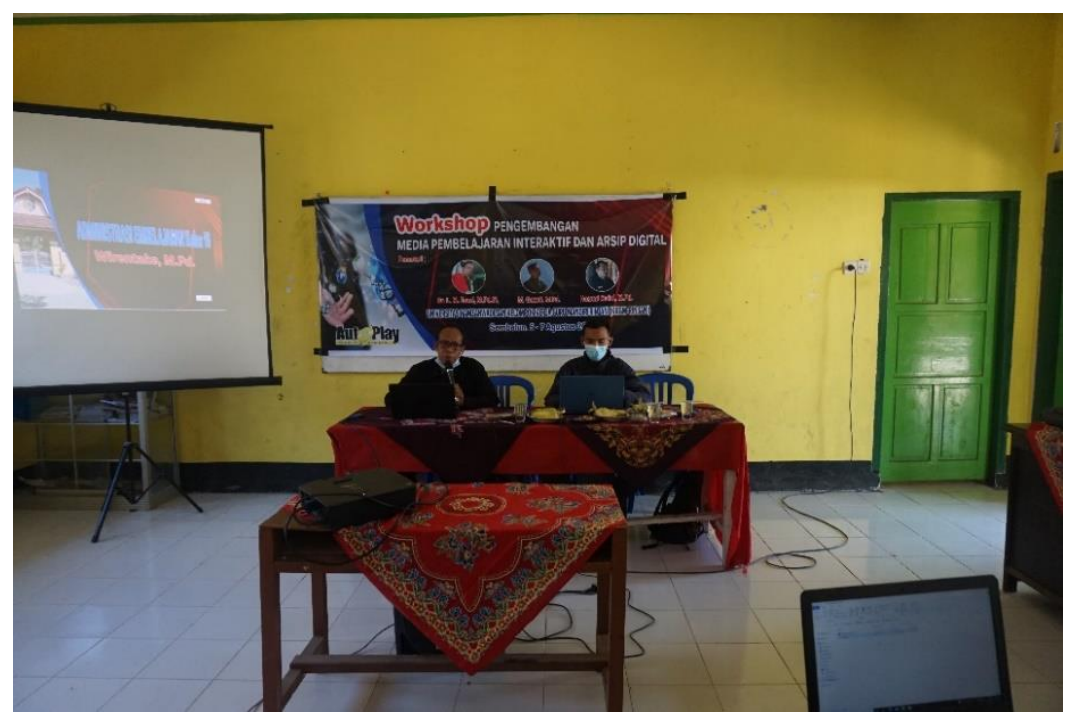

Gambar 2. Pemaparan materi penggunaan program Auto Play Media Studio 8.0 
Materi yang diberikan berdasarkan panduan praktik yang telah disiapkan, peserta langsung memulai praktik berdasarkan buku panduan dan arahan dari tim pengabdi.

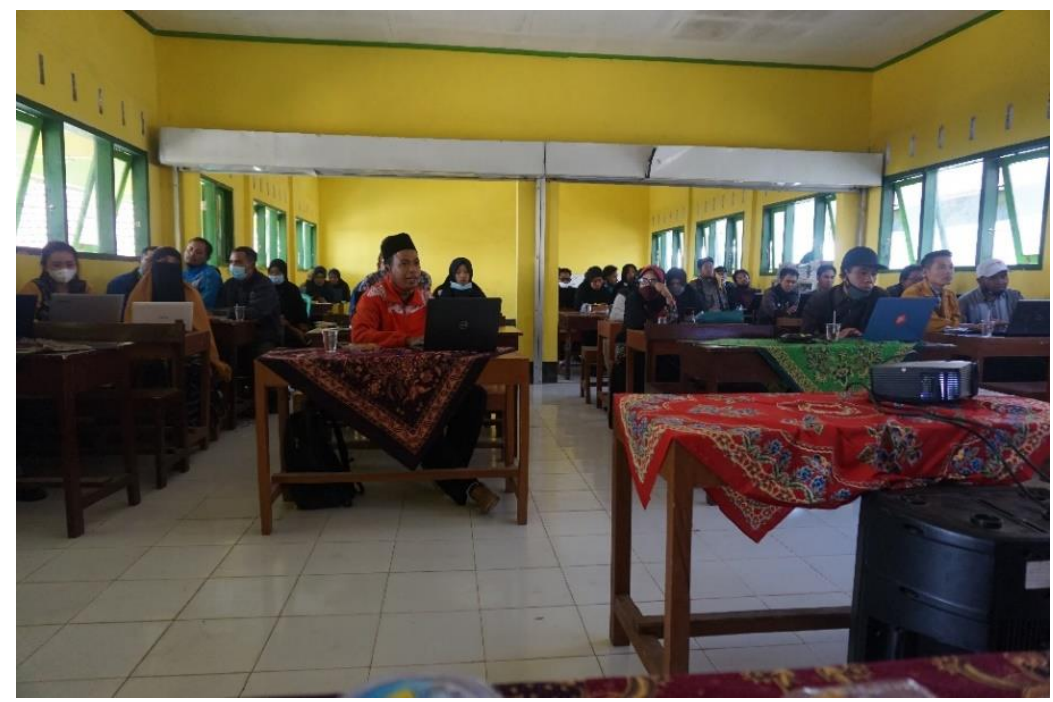

Gambar 3. Aktivitas peserta workshop

\section{Hari kedua}

Hari kedua adalah pembuatan media pembelajaran interaktif lanjutan dari hari pertama secara mandiri. Peserta dan tim pengabdian membuat grup WA untuk dijadikan sebagai alat komunikasi jika peserta menemukan kesulitan. Peserta secara intens bertanya terkait permasalahan yang dihadapi pada saat membuat media pembelajaran interaktif.

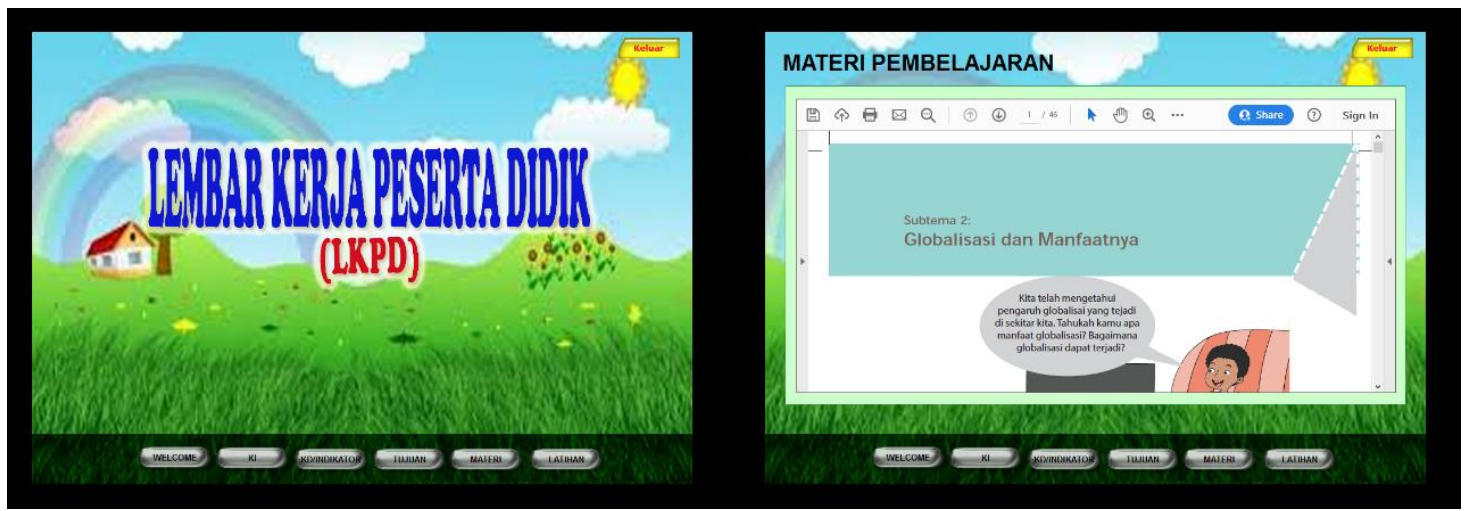

Gambar 4. Salah satu bentuk hasil peserta secara mandiri

Pada hari kedua peserta memberikan hasil yang telah dibuatnya dengan meminta masukan dari narasumber untuk perbaikan baik dari bentuk tampilan maupun dari sisi komposisi materi yang dimasukkan ke dalam aplikasi. Secara umum peserta mampu membuat media pembelajaran secara mandiri kalaupun masih banyak perbaikan-perbaikan dalam penyempurnaan namun media pembelajaran yang telah dibuat sudah dapat diimplementasikan dalam proses pembelajaran di kelas. 
Fauzi, L. M., Gazali, M., Mukti, H., Rahmawati, B. F. (2021) Workshop pembuatan media pembelajaran interaktif dalam memenuhi tuntutan pembelajaran Abad 21. ABSYARA: Jurnal Pengabdian Pada Masyarakat, 2(2), 185-194. doi:10.29408/ab.v2i2.4115

\section{Hari ketiga}

Hari ketiga merupakan evaluasi produk media pembelajaran yang dihasilkan oleh peserta. Pelaksanaan evaluasi dilakukan secara daring dengan mengirimkan bentuk desain dan aplikasi yang telah dibuat. Berdasarkan hasil dari seluruh peserta tim pengabdian dapat melihat perkembangan dari hasil workshop yang telah diadakan menunjukkan peserta sudah mampu membuat media pembelajaran interaktif menggunakan aplikasi Auto Play Media Studio 8.0, kalaupun masih sederhana namun ada beberapa hal yang rim temukan diantaranya adalah bentuk desain seperti tata letak, bentuk huruf, jenis dan warna background perlu diperhatikan sehingga media yang dibuat menjadi lebih menarik. Sedangkan yang lainnya sudah dianggap baik dan dapat diimplementasikan dalam pembelajaran.

Hasil dari kegiatan pengabdian kepada masyarakat yang telah dilakukan ini memberikan gambaran bahwa salah satu bentuk peningkatan kompetensi pedagogi guru adalah melalui pelatihan atau workshop sehingga kegiatan ini sangat penting untuk pengembangan diri bagi guru-guru. Pelatihan atau workshop memiliki manfaat yang mendalam bagi peningkatan kompetensi peserta serta menjadi bagian terpenting dalam peningkatan mutu pendidikan sebagaimana harapan dari pembelajaran abad 21 (Soenarko dkk., 2018; Sulistiyarini dkk., 2018; Suryani \& Khairudin, 2019)

\section{PEMBAHASAN}

Media pembelajaran merupakan sebuah alat penunjang dalam proses pembelajaran yang bertujuan untuk menyampaikan pesan sehingga siswa dapat termotivasi dalam mengikuti pembelajaran. Salah satu media pembelajaran untuk dikembangkan pada saat ini adalah media pembelajaran interaktif. Untuk membuat media pembelajaran interaktif salah aplikasi yang dapat digunakan adalah Auto Play Media Studio 8.0. program ini merupakan sebuah program yang sederhana namun memberikan hasil yang baik dalam mendesain media pembelajaran interaktif.

Keterbatasan media dan kurangnya kompetensi guru dalam mengembangkan serta membuat media pembelajaran interaktif untuk itu diadakan sebuah workshop pembuatan media pembelajaran interaktif dilingkungan kelompok kerja guru (KKG) - Rinjani Kecamatan Sembalun. Pelaksanaan kegiatan workshop Pembuatan Media Pembelajaran Interaktif yang dilaksanakan selama tiga hari tersebut yang diikuti oleh 55 peserta.

Pelaksanaan kegiatan pada hari pertama sebagaimana jadwal yang telah ada, kegiatan berlangsung sangat baik hal ini terlihat dari aktivitas peserta selama kegiatan, baik pada saat kegiatan pembukaan sampai dengan praktik pembuatan media pembelajaran kalaupun masih terdapat beberapa kendala yang terjadi selama kegiatan berlangsung. Namun kendala-kendala seperti yang dikemukakan pada hasil pelaksanaan di atas dapat diatasi dengan baik sehingga pelaksanaan berjalan sampai dengan akhir kegiatan pada hari pertama. Hari kedua merupakan kegiatan mandiri oleh seluruh peserta, peserta merancang dan membuat media pembelajaran secara mandiri yang nantinya akan dievaluasi hasil atau produk yang telah dibuat oleh masingmasing peserta pada hari ketiga. Jika dilihat perkembangan peserta dalam mendesain dan membuat media pembelajaran mengalami peningkatan hal ini terlihat dari hasil produk peserta yang telah disajikan pada hasil pelaksanaan di atas. Sedangkan hasil evaluasi menunjukkan bahwa peserta telah mampu membuat media pembelajaran interaktif dengan menggunakan 
Fauzi, L. M., Gazali, M., Mukti, H., Rahmawati, B. F. (2021) Workshop pembuatan media pembelajaran interaktif dalam memenuhi tuntutan pembelajaran Abad 21. ABSYARA: Jurnal Pengabdian Pada Masyarakat, 2(2), 185-194. doi:10.29408/ab.v2i2.4115

aplikasi atau program Auto Play Media Studio 8.0 dengan baik, namun untuk menyempurnakan hasil atau produk dari peserta membutuhkan banyak latihan.

\section{SIMPULAN}

Guru memiliki peran yang sangat penting dalam membina dan mengarahkan siswa untuk dapat berkompetisi di segala biang. Di era globalisasi dengan menerapkan pembelajaran abad 21 guru tidak hanya dituntut untuk pawai dalam memahami materi pelajaran akan tetapi guru juga harus mampu menggunakan dan memanfaatkan teknologi sebagai media dan sumber belajar. Untuk meningkatkan kompetensi guru sebagaimana yang diharapkan pada pembelajaran abad 21 adalah peningkatan kemampuan guru di bidang IT (teknologi informasi).

Dari hasil observasi pada Kelompok Kerja Guru (KKG) - Rinjani Kecamatan Sembalun, tim menemukan bahwa penguasaan guru di bidang IT (teknologi informasi) terutama pada penggunaan dan pembuatan media pembelajaran yang dapat digunakan dalam pembelajaran di masa pandemik Covid 19 seperti saat ini masih kurang. Berdasarkan permasalahan ini kami tim pengabdian memberikan workshop pembuatan media pembelajaran media interaktif dengan menggunakan aplikasi Auto Play Media Studio 8.0.

Hasil workshop memberikan gambaran bahwa peserta telah mampu membuat media pembelajaran interaktif dengan menggunakan aplikasi Auto Play Media Studio 8.0 kalaupun masih perlu perbaikan untuk penyempurnaan, akan tetapi hasil atau produk yang dibuat sudah dapat digunakan atau diimplementasikan dalam pembelajaran.

\section{PERNYATAAN PENULIS}

Artikel yang disusun oleh tim pengabdian ini merupakan artikel baru dan belum pernah diterbitkan pada jurnal lain.

\section{DAFTAR PUSTAKA}

Arianti, B. D. D., Kholisho, Y. N., \& Sujatmiko, S. B. (2020, May). The Development of ELearning Use MOODLE as A Multimedia Learning Medium. In Journal of Physics: Conference Series (Vol. 1539, No. 1, p. 012033). IOP Publishing.

Burns, M. (2011). Distance education for teacher training: Modes, models, and methods. Education Development Center. Inc. Washington, DC, 338.

Fauzi, L. M., Supiyati, S., \& Rasidi, A. (2020). Workshop Distance Learning di Masa Pandemic Covid 19. ABSYARA: Jurnal Pengabdian Pada Masyarakat, 1(1), 16-21. https://doi.org/10.29408/ab.v1i1.2405

Lase, D. (2019). Pendidikan di era revolusi industri 4.0. SUNDERMANN: Jurnal Ilmiah Teologi, Pendidikan, Sains, Humaniora dan Kebudayaan, 12(2), 28-43.

McDougall, J., \& Potter, J. (2015). Curating media learning: Towards a porous expertise. ELearning and Digital Media, 12(2), 199-211.

Sadiman, A. (2002). Media Pembelajaran dan Proses Belajar Mengajar, Pengertian Pengembangan dan Pemanfaatannya. Jakarta: Raja Grafindo Persada.

Samsuri, T., Muliadi, A., Muhali, M., Asy’ari, M., Prayogi, S., \& Hunaepi, H. (2020). Pelatihan desain media interaktif pada pembelajaran daring bagi dosen pendidikan biologi. ABSYARA: Jurnal Pengabdian Pada Masyarakat, 1(2), 30-35. https://doi.org/10.29408/ab.v1i2.2745 
Soenarko, B., Wiguna, F. A., Putri, K. E., Primasatya, N., Kurnia, I., Imron, I. F., ... \& Wahyudi, W. (2018). Pelatihan Pembuatan Media Pembelajaran Interaktif dengan Memanfaatkan Bahan Bekas untuk Guru Sekolah Dasar pada Anggota Gugus 2 Kecamatan Ringinrejo Kabupaten Kediri. Jurnal ABDINUS: Jurnal Pengabdian Nusantara, 1(2), 96-106.

Sulistiyarini, D., Bibi, S., Fatmawati, E., \& Arpan, M. (2018). Pelatihan pembuatan media pembelajaran interaktif di SMP dan SMK Mandiri Pontianak. GERVASI: Jurnal Pengabdian kepada Masyarakat, 2(1), 39-46.

Sumantri, M. S., \& Rachmadtullah, R. (2016). The effect of learning media and self regulation to elementary students' history learning outcome. Advanced Science Letters, 22(12), 4104-4108. https://doi.org/10.1166/as1.2016.8140

Suryani, K., \& Khairudin, K. (2019). Pelatihan Pembuatan Media Pembelajaran Interaktif Menggunakan Aplikasi Lectora Di Smk Muhammadyah 1 Padang. GERVASI: Jurnal Pengabdian Kepada Masyarakat, 3(1), 58. https://doi.org/10.31571/gervasi.v3i1.1197

Vebrianto, R., \& Osman, K. (2011). The effect of multiple media instruction in improving students' science process skill and achievement. Procedia - Social and Behavioral Sciences, 15(December), 346-350. https://doi.org/10.1016/j.sbspro.2011.03.099

Vinod Bhatia, K., \& Pathak-Shelat, M. (2017). Media literacy as a pathway to religious literacy in pluralistic democracies: Designing a critical media education pedagogy for primary school children in India. Interactions: Studies in Communication \& Culture, 8(2-3), 189-209.

Zawacki-Richter, O., Müskens, W., Krause, U., Alturki, U., \& Aldraiweesh, A. (2015). Student media usage patterns and non-traditional learning in higher education. International Review of Research in Open and Distance Learning, 16(2), 136-170. https://doi.org/10.19173/irrodl.v16i2.1979 